RESEARCH NOTES

\title{
Problems of Legal Regulation of Robotics and Artificial Intelligence from the Psychological Perspective
}

\section{Problemas de regulación legal de la robótica y la inteligencia artificial desde la perspectiva psicológica}

\author{
Pavel P. Baranov* \\ ORCID: https://orcid.org/0000-0001-7062-5266 \\ Aleksey Yu. Mamychev \\ Vladivostok State University of Economics and Service, Vladivostok, Russia \\ ORCID: https://orcid.org/0000-0001-6043-8141 \\ Andrey A. Plotnikov \\ Northern (Arctic) Federal University, Russia \\ ORCID: https://orcid.org/0000-0003-0889-4160 \\ Dmitry Yu. Voronov \\ Togliatti State University, Russia \\ ORCID: https://orcid.org/0000-0002-5233-7276 \\ Elena M. Voronova \\ Togliatti State University, Russia \\ ORCID: https://orcid.org/0000-0003-2723-4088
}

Russian Presidential Academy of National Economy and Public Administration, Russia

Received 12-27-19 Revised 02-02-20 Accepted 04-20-20 On line 04-30-20

*Correspondence

Email: pravosoznanie@gmail.com
Cite as:

\footnotetext{
Baranov, P. P., Mamychev, A. Yu., Plotnikov, A. A., Voronov, D. Yu., \& Voronova, E. M. (2020). Problems of Legal Regulation of Robotics and Artificial Intelligence from the Psychological Perspective. Propósitos y Representaciones, 8(2), e511. doi: http://dx.doi.org/10.20511/pyr2020.v8n2.511
} 


\section{Summary}

The article analyzes the main problems and contradictions in the formation of legal regimes for the regulation of robotics, artificial intelligence and other innovative technologies of our time. The work content shows the unpreparedness of modern legal science and practice to conceptual and legal design, legal and technical development of the regulatory legal acts aimed at the legislative fixation and regulation of the processes of using artificial intelligence and robots in public relations, as well as definition of responsibility and appropriate protection modes of legitimate interests, rights, freedoms in the system of personality - society - state. The subject of this study is the resolution of these problems and contradictions, as well as the identification of directions for the formation of a legal framework for the regulation of modern innovative technologies and digital processes unfolding in the modern society. The authors distinguish and analyze two consecutive stages: 1) development and introduction of necessary changes in the existing branches of Russian law; 2) conceptual-legal and doctrinal-legal formulation of key development priorities, as well as creation of a new integrated branch of law - robotics law, which has an independent subject and method of legal regulation.

Keywords: Drones; Innovative Technologies; Artificial Intelligence; Law; Legal Regimes; Robotic Technologies; Electronic Person.

\section{Resumen}

El artículo analiza los principales problemas y contradicciones en la formación de regímenes legales para la regulación de la robótica, la inteligencia artificial y otras tecnologías innovadoras de nuestro tiempo. El contenido del trabajo muestra la falta de preparación de la ciencia y práctica legal moderna para el diseño conceptual y legal, el desarrollo legal y técnico de los actos legales regulatorios destinados a la fijación legislativa y la regulación de los procesos de uso de inteligencia artificial y robots en las relaciones públicas, así como definición de responsabilidad y modos apropiados de protección de intereses legítimos, derechos, libertades en el sistema de personalidad - sociedad - estado. El tema de este estudio es la resolución de estos problemas y contradicciones, así como la identificación de direcciones para la formación de un marco legal para la regulación de tecnologías modernas innovadoras y procesos digitales que se desarrollan en la sociedad moderna. Los autores distinguen y analizan dos etapas consecutivas: 1) desarrollo e introducción de los cambios necesarios en las ramas existentes de la ley rusa; 2) formulación conceptual-legal y doctrinal-legal de prioridades clave de desarrollo, así como la creación de una nueva rama integrada del derecho: la ley de robótica, que tiene un tema y un método de regulación legal independientes.

Palabras clave: Drones; Tecnologías innovadoras; Inteligencia artificial; Derecho; Regímenes legales; Tecnologías robóticas; Persona electrónica.

\section{Introduction}

Now there are more and more gaps in the law, requiring their replenishment. So, for example, there is a new object and, probably, a new subject - robotics and artificial intelligence - in the legal field in the near future. It should be recognized that to date there are no legal definitions and no principles of legal development of public relations related to interaction with robotics and artificial intelligence, no legal regimes of legislative regulation - use, application of these facilities in public life, as well as protection of human rights and freedoms (and possibly the very artificial intelligence) in the context of these relations.

Firstly, all this leads to the fact that the uncertainty of the notions "artificial intelligence", "robot", "robotic technologies" and so on, creates not only theoretical gaps in the jurisprudence, but (which is more significant) does not allow legislatively regulating a significant part of the 
government process management mechanism associated with the proliferation and use of artificial intelligence and robots. Secondly, the theoretical and methodological understanding and definition of these concepts creates the opportunity to bring the actual legal regimes of functioning of the state apparatus in line with the new realities of development of social relations, technologies and innovation processes in various fields of society.

Today, the robots and artificial intelligence are increasingly penetrating the human realm. The USA, China, Japan, the EU, South Korea are very serious about robotics and officially recognize that it is the thing of the future. Accordingly, the issues of legal regulation of robotics come to the fore against the background of competition in this field, which can lead to tangible technological and economic results. For example, the Law on Development and Promotion of Intelligent Robots, adopted in South Korea in 2008, made it possible to increase their production by $80 \%$ and bring the state more than $\$ 4$ billion income in 2016 . Therefore, the state support can accelerate development in this area, and other countries will be oriented to the standards created at the same time.

It should be noted that the Russian Federation is significantly lagging behind in terms of creating common principles with other countries for regulating this field. And procrastination here threatens the country by the fact that various regulations and rules of the game in this field, which are already being developed in the West European legal framework, will be subsequently imposed on "lagging countries".

For example, the European Parliament voted in favor of a resolution on regulating the development of robotics and artificial intelligence within the European Union in February 2017. Taking into account the recommendations given by the Committee on Legal Affairs, the proposed rules include the development of ethical standards for the development of artificial intelligence and the introduction of an insurance system to cover liability for road traffic accidents involving self-managed vehicles.

In this regard, the lack of a doctrinal and legal level, as part of the development of constitutional and legal ideas and practices, as well as problems in the legal regulation of processes related to the development and integration of artificial intelligence and robots, including robotic technologies, into social life and social interaction, leads to serious challenges to national and global security (Ovchinnikov, Mamychev,\& Baranov, 2017; Constitutional and Legal Policy of Modern Russia), to a serious lag in the legal development of public relations (Baranov, Ovchinnikov, Mamychev, \& Plotnikov, 2017), to the possibility of effective "legal coding" and public-power management of these processes (Baranov, Lyubashit, Mamychev, Kuchina, \& Shestopal, 2017).

\section{Methods and Materials}

The above gaps in law have an obvious objective and subjective sides. Firstly, the modern law theorists and lawmakers are simply not ready for conceptual, legal and doctrinal legal developments in this field, as well as for the subsequent adoption of the necessary regulatory and legal acts regulating the use of artificial intelligence and robots in social interaction, the definition of responsibility and corresponding regimes of protection of legitimate interests, rights, freedoms, etc. in the system of personality - society - state. In many respects this is due to the fact that social relations are in constant dynamics in this field, they differ in novelty and complexity degree, so it is not clear how and with what legal means they should be regulated. The lack of proper legal and legislative equipment, the imperfection of the legislation itself can be attributed to the subjective factors hampering the development and adoption of the appropriate legal framework for the regulation of the above-mentioned processes.

At the same time, it is necessary to develop this direction in the legal science, the perfection of legal techniques, the development and adoption of a set of regulations that would be 
able to form at least a general legal framework for the development of these discussed innovative processes in the society. Estonia reached great success in developing the law on robots. The law being developed is not only about the self-guided unmanned vehicles, but also about the creation of a new legal entity, the so-called electronic person, and the possibility of determining the degree of responsibility of the artificial intelligence. The developers plan to prepare this regulatory legal act in the next two years.

In legal science, the topic under consideration has not yet received adequate coverage. As first attempts, it is possible to name only separate articles, which pose the issues of legal regulation in the field of robotics and artificial intelligence (Cherkasov, 2017; Uzhov, 2017; Arkhipov \& Naumov, 2017).

The formulation and consideration of these issues is important, first of all, from the position of human rights, not the robot. For example, who will be guilty in cases of errors of autonomous robotics? Is it possible to bring the perpetrator to legal liability in accordance with the current legislation?

\section{Main Part}

In December 2016, the Head of the Board of Directors of Mail.ru and the founder of Grishin Robotics, Dmitry Grishin, presented his concept of the law on robotics, where he proposed to treat robots as animals and legal entities in the Russian Federation. According to this expert, the intelligent machines cannot be the subjects of law, as they are devoid of emotions. Nevertheless, machines can make autonomous actions, like the same animals, and therefore they should be the legal objects. At the same time, Grishin emphasizes that it is necessary to establish the responsibility of developers of robotics, which can cause damage to people, as well as it is necessary to create a common unified international register of robots. Not so long ago, the company HEADS Consalting stood with an important initiative of creating a cybercode as the code of laws.

And what do our legislators think about all this? They, as always, hesitate. The Chairman of the State Duma of the Federal Assembly of the Russian Federation Vyacheslav Volodin stated that the deputies needed to prepare a bill on regulating the relationship between a robot and a person during his working trip to Tatarstan in February 2017. At the same time, the Chairman of the State Duma believes that Russia can become a pioneer in the legal regulation of the development of robotics and artificial intelligence and develop such a law by 2022 .

In our opinion, a significant correction of legal regulation in this area is required to create the conditions for the introduction of robotics in such areas as medicine, transport, road traffic, insurance, etc.

Firstly, the domestic legal science should work out, together with all interested parties, a common set of important principles that will be used as a basis for the development of a future federal law on robotics and those changes that affect industry legislation. The rationale for these principles may relate to the revision of certain provisions of the general theory of law relating primarily to the theory of legal relations, including issues of legal capacity and capability of the subjects and objects of legal relations, legal facts and their classification, etc.

\section{Robot: Regulation Legal Framework}

The formation of legal framework of this field should begin with the definition of the concept of "robot", "robotics" and "artificial intelligence". It cannot be said that these concepts are completely absent in the legal field of Russia. As a rule, these concepts are used from time to time at the level of subordinate legal acts. For example, the importance attached to the concept of artificial intelligence is evidenced by its mention in the strategies of scientific and technological 
development of the Russian Federation and the development of the information society in the Russian Federation for 2017-2030 (The Decree of the President of the Russian Federation No. 642, Decree of the President of the Russian Federation No. 203). The term "robot" can be found, for example, in the Order of the Ministry of Labor of Russia No. 799n dated October 29, 2015 "On Approval of the Professional Standard "Operator of Dismantling Robots Designed for Work in High Radiation Fields". However, there is no single understanding of the problem, as well as the corresponding systematization of the categorical apparatus in this field in modern Russian law at present.

In our opinion, in a broad sense, the term "robot" could be defined as "a programmable autonomous automatic device capable of performing various manipulations and interacting with the environment without the help of a human and replacing their work". At the same time, it should be noted in the legislation that robots can be of three categories: industrial, research and educational. By their origin, robots can be of domestic production, foreign production and coproduction.

At its core, the robot is a movable electromechanical object that operates according to the program embedded in it and is a closed system with its own resources. However, a robot cannot be absolutely completely autonomous even from an economic point of view, since it has its owner.

And yet, according to most scientists and experts, the robot is just different from other mechanisms that make the human work easier due to the autonomy of their behavior, as it collects the surrounding information, independently processes it and draws certain conclusions. At the moment, the robots are considered to be the mechanisms fulfilling the human will in most developed foreign countries. But in the near future, the robots can reach the absolute degree of their autonomy and then it will be possible to talk about them as special subjects of law, participants in the civil-law turnover, having their own legal responsibilities and being responsible for their behavior. developed:

In our opinion, the following features of the robot should be fixed in the legislation being

- own autonomy,

- availability of software and mechanism,

- ability to produce certain physical actions in space,

- safety for people and presence of the function of blocking the possibility of causing harm to people.

Robotics, in our opinion, could be defined as "a scientific and technical base for the design, production and use of robots in practice".

\section{Artificial Intelligence: Regulation Legal Framework}

The artificial intelligence is the scientific direction developing the methods that enable the electronic computers to solve intellectual problems independently, if they are solved by people. In our opinion, artificial intelligence can be defined as "the aggregate of the functional capabilities of an electronic computer to solve human problems".

The basic principles that should be reflected in the legislation on robotics and artificial intelligence include:

- Unquestionable priority of human rights and their protection in the use of robots and artificial intelligence. 
- The responsibility of robot developers and owners for what they do. In this case, one should consider the autonomy of robots in decision-making. The higher the autonomy is, the lesser the responsibility should be borne by the robot owner.

- A robot is just a thing, it cannot be humanized or considered a person. It is devoid of selfawareness and emotions and differs even from animals in this regard. Therefore, robot humanizing is no less important problem than, for example, robot-crime. Balancing is on the brink of ethics and law here. And if one can defend some neutral position in the ethical sphere, then the law cannot tolerate vague formulations.

- The introduction of a special liability insurance for damage caused by the robot (by analogy with OSAGO), which will allow a person injured by the robot's activity to receive a guaranteed compensation.

- Strict state control over the production and distribution of autonomous military robots, because it is quite possible to create robots that are capable of independently deciding on killing an enemy.

\section{Electronic Person: Regulation Legal Framework}

It is also necessary to discuss the issue of the possibility of introducing a new legal status of "electronic person" for robots, which in principle could allow them being included in the existing system of civil liability. At the same time, the civil law should stipulate a provision on the right to establish cause and effect relationships between the robot's actions (inactions) and the damage it has caused to be able to recover compensation from the robot manufacturer.

In the near future the labor market will change, as there will be robot prototypes of drivers, doctors, lawyers, policemen, musicians, etc. It is the theoretical possibility of the substitution of most legal professions by robots, which is of particular concern to the modern legal community (Ralko, 2016; Bychkov, 2016). In this regard, it will appear the issues about granting the robots with certain rights and responsibilities and whether such objects can have a freedom of choice in principle. At the same time, it may arise a very important question about whether the robots can be aware of the consequences of their actions and make some moral choice in difficult situations. Robots can be as smart (if not smarter) as people, but they can hardly have such important threshold ethical manifestations as experiencing pain and empathy, having self-consciousness, looking at things and their actions from the standpoint of morality.

In our opinion, the entire problem will be centered around the issue about the degree of robot autonomy and real possibilities to measure and evaluate this autonomy.

\section{Improvement of the Current Legislation}

According to scientists, $75 \%$ of information will be created by electronic computers by 2020 . Gradually these devices will become the economic entities. Therefore, it would be logical to give them economic powers, for example, the right to make various payments. And the most important role will be played by the existing blockchain technology (the so-called digital transaction register or chain of transaction blocks). The American company Hanson Rubotics plans to introduce the blockchain technology into the artificial intelligence in the near future.

The American company Google has taught artificial intelligence to independently create artificial intelligence, which exceeds the effectiveness of similar systems created by people. The AutoML ("automated machine learning") project was launched in May 2017. The project goal is to create the neural networks with the help of artificial intelligence. The systems created in this way determine the displayed images in $82 \%$ of cases. The best result in such experiments among the neural networks created by human is only $39 \%$. That is, the artificial intelligence creates an independent artificial intelligence, which is at least twice as effective as the artificial intelligence created by human. 
At the same time, the artificial intelligence cannot replace a person, since it is not able to improve himself without creative human decisions, although the foreign scientists are carrying out an active work in this field. For example, German scientists have developed the software algorithms, the application of which allows, in turn, creating an algorithm called "touch for robots". The American scientists have found a way to create a sensory "skin" for robots, through which they can touch the objects.

All of the above can be the basis for introducing changes in the sectoral legislation, especially in the Civil Code of the Russian Federation. In particular, we can talk about clarifying the provisions of Art. 1079 of the Civil Code of the Russian Federation "On liability for Damage Caused by Activities Creating an Increased Danger to Others", because it arises the issues as to whether the robots are recognized as a source of increased danger, what are the criteria for this?

In our view, the sources of increased danger should be understood in in civil law as various things that have dangerous properties, and the operation of these things cannot be fully controlled by a person. In the case of causing damage to property by a robot, the robot owner will bear the responsibility as the owner of a source of increased danger. But then the robots should be recognized as an object of civil law and civil turnover. In this case, the robots will be included in the list of objects of legal regulation, like, for example, pets. It is quite another matter, if the robots are assigned to the subjects of law that will have legal personality. Some domestic experts come to the conclusion that robots are consistent with the doctrine of a legal entity. Therefore, the civil law rules on legal entities may and should apply to robots.

The field concerned will need some changes in the criminal legislation. If, for example, a robot commits a murder, then the robot will be considered only as a murder weapon of its owner according to the existing position in accordance with Art. 105 of the Criminal Code. Therefore, in our opinion, it is necessary to develop special articles on crimes committed using special technical means - robots.

\section{The Main Stages of Development and Improvement of Legal Regulation of the Development of Innovative Technologies}

In our opinion, all work on the legal regulation of the filed in question should be built consistently and in stages.

At the first stage, in addition to introducing appropriate changes to the sectoral legislation, as discussed above, the efforts should be concentrated on the legal regulation of unmanned aerial vehicles or drones, which are widely used in various field of life.

Firstly, it was amended the Air Code of the Russian Federation in March 2016, which obliged the drone owners weighing more than $250 \mathrm{~g}$ to register them in the Federal Air Transport Agency. But already on June 21, 2016 the State Duma adopted amendments to the Air Code of the Russian Federation that the above-mentioned rule on drone registration in the Federal Air Transport Agency concerned only those of them weighing more than $30 \mathrm{~kg}$. However, these provisions do not solve a huge number of existing problems in the least. The Federal Law No. 462-FZ dated December 30, 2015 "On Amendments to the Air Code of the Russian Federation with Regard to the Use of Unmanned Aircraft" has not yet been upheld by the necessary legal acts. Therefore, the implementation of this law is difficult. The problems of registration of unmanned aerial vehicles, the certification of pilots (operators), the procedure for establishing responsibility for the misuse of drones and for possible damage inflicted by drones are poorly regulated. 
Also, the problem of legal regulation of using the drones in the Armed Forces and the Federal National Guard Troops Service, in which they are already actively used, has not yet been solved.

Another relevant problem we consider is the legal regulation of unmanned vehicles, which may soon appear on our roads.

In March 2016, Russian lawmakers, when discussing this issue, offered to allow using the unmanned vehicles on public roads in case that there is a driver in the cabin, who will be able to change control to manual mode, if necessary. It was proposed to define the concept of an unmanned vehicle as a mechanical vehicle equipped with an automatic control system that can be operated without driver involvement. It was supposed to make changes to the Articles of the Federal Law No. 196 "On Road Safety", Criminal, Civil Codes and the Code of Administrative Offenses. But, unfortunately, these proposals have so far remained only proposals.

Then, in our opinion, it would be necessary to prepare a basic Federal Law "On Robotics and Artificial Intelligence" for all robotics, which include general principles, concepts and provisions, as we discussed above.

In theory, at the second stage it would be necessary to comprehend and work out the issue of creating a new complex branch of law - robotics law (some experts talk about "unmanned law" or "machine law"), which has an independent subject and method of legal regulation. The subject of this new industry will be a set of legal norms governing public relations in the development, production and use of various robots and related to different branches of law. This complex industry will have to include the norms of public law - constitutional, criminal, administrative, land, etc., where the relations are built on the basis of domination of state power over all entities, and the norms of private law branches in which the participants are equal and autonomous.

\section{Conclusions}

In conclusion, we would like to say the following. We often hear that in the conditions when the robots are still used quite rarely Russia and there are serious problems in the economy, legal regulation of robotics is at least untimely. However, one should keep in mind that legal regulation in this area is necessary for the development of standards, without which it will be impossible to effectively develop robotics and artificial intelligence in Russia.

The very process of forming a legal framework for regulating these processes should be developed in two consecutive stages. The first stage involves the development and introduction of necessary changes in the existing branches of Russian law. At the same time, the main efforts of the scientific community, experts and legislators should be concentrated on creating legal regimes for the regulation of unmanned aerial vehicles or drones, which are widely used in various fields of life. In turn, the second stage should become a conceptual-legal and doctrinal-legal, that is, aimed at theoretical understanding of domestic and foreign experience, the doctrinal and legal formulation of key development priorities, as well as the creation of a new integrated branch of law - robotics law, which has an independent subject and method of legal regulation.

\section{References}

Arkhipov, V. V., \& Naumov, V. B. (2017). Information and Legal Aspects of Forming the Legislation on Robotics. Information Law, 1, 19 - 27.

Baranov, P., Ovchinnikov, A., Mamychev, A., \& Plotnikov, A. (2017). Elites and the Formation of Constitutionalism: The Socio-Cultural Vector of Development. Man in India, 97(23), 561- 575. 
Baranov, P., Lyubashits, V., Mamychev, A., Kuchina, Y., \& Shestopal, S. (2017). Dynamics of governmental organization of the society: Evolutionary state-legal forms and modern development trends. Man in India, 97(23), 543-550.

Bychkov, A. (2016). Robots-Lawyers of the Future. How the Market of Legal Services is Changing. Financial Newspaper, 33, 11 - 12.

Cherkasov, V. N. (2017). A New Subject of Law?. Basis, 1, 41-44.

Constitutional and Legal Policy of Modern Russia: Ideas, Priorities, Values, Directions: Monograph. M.: RIOR, INFRA-M. 2018. p. 248

Decree of the President of the Russian Federation No. 203 dated May 9, 2017 "On the Strategy for the Information Society Development in the Russian Federation for 2017 - 2030". (2017). Official Gazette of the Russian Federation. May 15, 20. Art. 2901.

Ovchinnikov, A. I., Mamychev, A. Yu., \& Baranov, P. P. (2017). Fundamentals of National Security. M.: RIOR, INFRA-M, p. 224

Ralko, V. V. (2016). The Notary's Future. Notary, 8, 8 - 11.

The Decree of the President of the Russian Federation No. 642 dated December 1, 2016 "On the Strategy of Scientific and Technological Development of the Russian Federation". (2016). Official Gazette of the Russian Federation. December 5, 49, Art. 6887.

Uzhov, F. V. (2017). Artificial Intelligence as a Subject of Law. Gaps in Russian Legislation, 3, 357-360. 